\title{
THE JUDICIAL CORRECTION OF JUDICIAL ERRORS
}

A most interesting problem is presented by a recent incident in the jurisprudence of the State of New York.

$$
\text { * * * * * * * }
$$

There has never been a time in the history of the chief city of that State when an encroachment upon the street by an abutting owner has been anything other than a trespass upon public property, and a public nuisance; yet from time immemorial the officials of that city have permitted, or have attempted to legalize, encroachments of many feet beyond the street line, and have connived at a continuous obstruction of public traffic which has been fairly scandalous. They have even enacted municipal ordinances regulating the extent to which encroachments would be permitted." These ordinances have created the locally famous "stoop line," which is merely an imaginary line on the sidewalk to which abutting owners were tacitly permitted to extend their front steps, or stoops, and other projections from the building, and beyond which they were warned that they must not go. Even at that, however, many encroachments were carried beyond the stoop line, and the city authorities were conveniently blind to the resulting obstruction of traffic. For years plans for such encroachments have been approved by the Building Department in direct violation of even the lax provisions of the ordinances.

The courts themselves have connived at this violation of the law. There is a long series of decisions in which they sustained obstructions on the public highways. Thus, in an action brought by the People to compel the removal of a shed on a public pier erected pursuant to a permit from the Building Department, the Court of Appeals held that the shed could be legally constructed.2 Again, officials of the city charged with the duty of removing obstructions on the street were enjoined from removing an iron awning which, in accordance with an express ordinance of the Common Council, covered the entire sidewalk. ${ }^{3}$ An act of the

\footnotetext{
1 Cosby, Code of Ordinances, p. 54, $\S 247$, and note; see also, ibid., p. $46, \S 219$, and note.

2 People v. B. \&. O. R. R. Co. (1889) II7 N. Y. 150, I55.

'3 Hoey v. Gilroy (I89I) I29 N. Y. 132.
} 
legislature authorizing a limited use of the sidewalks in front of buildings for stoops, cellar openings or underground vaults for the more convenient and beneficial enjoyment of the adjacent premises was sustained. ${ }^{4}$ The court refused to enjoin, on complaint of one property owner, the construction of encroaching bay windows by an adjoining property owner. ${ }^{5}$ The climax of these decisions was reached in two opinions from which it will be pertinent to take extracts.

In the case of Broadbelt $v$. Loew ${ }^{6}$ the defendant objected to a title which the plaintiff tendered to him under a contract of sale. The objection was that certain bay windows illegally projected beyond the street line and constituted a defect which rendered the title unmarketable. The Appellate Division, an intermediate appellate tribunal, declared the title good. In the course of its opinion, the court expressed itself in the following terms:

"In view of the ordinances of the common council of the city of New York and of the acquiescence of the authorities of the city in the allowance of constructions such as those connected with the plaintiff's houses, the possibility of the owner ever being molested is so exceedingly remote that the objections become technical only and not substantial."

The judgment was subsequently affirmed by the Court of Appeals "on the opinion below," which means that the Court of Appeals expressly adopted this opinion as an accurate expression of its own views. ${ }^{7}$ A little later the same Appellate Division in the case of Levy v. Hill dismissed an action brought by the plaintiff to obtain an allowance from the purchase price fixed in a contract for the purchase of certain premises on 34th Street, because of the fact that the front stoop projected beyond the building line and encroached on the street. The court dismissed the complaint, using this language:

"This stoop has been in its present condition for upwards of thirty years without objection on the part of the municipality or any of the adjoining property owners. That any serious objection by any one could now be made to the continuance of this stoop in the condition

\footnotetext{
4 Jorgensen v. Squires (1895) 144 N. Y. 280.

${ }^{5}$ Wormser v. Brown (1896) 149 N. Y. 163.

6 (1897) I5 App. Div. 343.

T (1900) 162 N. Y. 642.

8 (1900) 50 App. Div. 294.
} 
it is in, is such a remote contingency that it could hardly

be considered a serious objection to the title."

Such was the state of the decisions in I900, when the Broadbelt and Levy cases were decided. In I903, however, out of a clear sky, came the case of Ackerman $v$. True. ${ }^{9}$ In that case the Court of Appeals held that Mrs. Charlotte Y. Ackerman, the plaintiff, was entitled to an affirmative order requiring the owner of adjoining property to remove a bay window which he had constructed and which projected over the public highway. This case was immediately followed by a flood of decisions in the Appellate Division and in the Court of Appeals itself declaring in no uncertain terms that an encroachment on the street is a trespass upon public property and a public nuisance, which neither the legislature of the State nor the municipal authorities can lawfully authorize. ${ }^{10}$ These cases approach the question from practically all possible angles. Encroachments were enjoined at the instance of adjoining owners, public officials were required by writs of mandamus to remove them, and, at least in cases in which they constituted a structural part of the abutting building, they were held to create a defect in the title.

This change in the views of the courts was more than merely legal: it brought about an enormous property loss as well. The municipal authorities swept through the principal business streets of the city like a besom of destruction and removed, or required the owners to remove, all encroachments beyond the street line. Some of these had been standing for years; some of them were structural parts of buildings; all of them had been sanctioned by the several authorities of the city government; and one, at least, that in the Levy case, had been specifically sanctioned by the courts themselves. The cost to the citizens mounted into the millions, and, as the process will undoubtedly continue, there is no visible limit to the ultimate total.

How complete was the change in the position of the courts

${ }^{8}$ (I903) I75 N. Y. 353.

${ }^{10}$ City of N.Y. v. Knickerbocker Trust Co. (1905) I04 App. Div. 223; McMillan v. Klaw \& Erlanger Co. (1905) ro7 App. Div. 407; Williams v. Silverman Realty \& Constr. Co. (1906) III App. Div. 679; Hatfield v. Straus (1907) I17 App. Div. 671, affirmed (1907) 189 N. Y. 208; People ex rel. Cross v. Ahearn (1908) I24 App. Div. 840; People ex rel. Brozening, King \& Co.v. Stover (I9II) r45 App. Div. 259; City of N.Y. v. Rice (1910) 198 N. Y. 124; Acme Realty Co.v. Schinasi (19r3) I54 App. Div. 397, affirmed (I915) 215 N. Y. 495. 
will be indicated by a comparison of the opinions in the Court of Appeals. The fundamental question, of course, relates to the legislative power to authorize encroachments on the street. On this point the court in the Jorgensen case said:

"It is competent for the legislature to authorize a limited use of sidewalks in front of buildings in cities and villages for stoops or cellar openings or underground vaults for the more convenient and beneficial enjoyment of the adjacent premises."11

In the Ackerman case, on the other hand, the same court, speaking of a statute which was claimed by counsel to authorize the encroachment there in question, used the following language:

\begin{abstract}
"Moreover, if that statute were to be thus construed, its constitutionality would be at least doubtful, for even the legislature cannot authorize the condemnation of private property for other than public uses. The effect of a construction which would permit the park board or any of its members to sell or give the right to obstruct the streets or highways therein, could not be otherwise than detrimental to and destructive of the interests of the municipality and its inhabitants."12
\end{abstract}

On the hardly less important question as to whether or not the legislature, granted that it had the power to authorize encroachments, had actually delegated it to the municipal authorities, the Court of Appeals, after reviewing a long series of statutes, reached the conclusion that the legislature had conferred upon the department of public parks the power to authorize encroachments upon the parks and the streets in and around them and had conferred upon the common council the power to authorize encroachments on all other streets. ${ }^{13}$ In the Ackerman case, on the other hand, the court, upon a construction of a series of statutes which were substantially identical, declared:

"It becomes quite manifest, we think, that the legislature did not intend thereby to confer upon a member of the park board the right to permit an abutting owner upon any of the streets of the city, whether within any park or outside, to encroach upon the street by the erection of permanent and substantial structures thereon. ${ }^{14}$

11 Jorgensen v. Squires (1895) I44 N. Y. 280, 284.

12 Ackerman v. True (rg03) I75 N. Y. 353, 365.

13 Wormser v. Brown (1896) 149 N. Y. 163, 167-170.

14 Ackerman v. True (1903) 175 N. Y. 353, 365. 
A detailed comparison of the opinions of the Court of Appeals will disclose various other inconsistencies, but we have given enough to make clear the radical character of the change in views. It was so radical, indeed, that the Court of Appeals at last felt itself compelled to explain how it had come about. The explanation which it offered is to be found in the case of Acme Realty Co. v. Schinasi. ${ }^{15}$ In that case it affirmed a judgment of the Appellate Division holding that an encroachment on the street, which was a structural part of an abutting building, constituted a defect in title which relieved an intending purchaser from his contract to purchase, although the encroachment was only a foot in depth. The pertinent passages of its opinion are as follows:

"We have decided to adopt the views expressed by Mr. Justice Clarke in the excellent opinion which he wrote in the case at bar for the majority of his associates at the Appellate Division; but we deem it proper to supplement them with a few observations designed to emphasize the reason for the apparent conflict between the cases cited by the referee in support of his decision in favor of the plaintiff [i.e., the Broadbelt and other like cases], and the more recent adjudications upon which the Appellate Division relies to justify its judgment in favor of the defendant. We shall endeavor to do this without a categorical review of the numerous decisions on the subject.

"The reason for the difference between the earlier and the later judicial decisions on the subject is to be found in the changed public policy of the municipality. The case of Broadbelt (supra) was decided by the Appellate Division in 1897 , and by this court in 1900 . From time almost immemorial it had been the municipal policy to acquiesce in the practically universal custom of encroaching upon the streets with various building projections. This policy had its genesis in the infancy of the city and it had been continued without interruption. Although the population had reached a large proportion when the case of Broadbelt was decided, it has since then multiplied in a constantly ascending ratio of rapidity. The growing density of population, and the spread of business into districts that were formerly devoted wholly to residential structures, have created many perplexing problems in connection with the use of the streets as public highways. It is familiar recent history that these changed conditions have led to the compulsory removal of buiding encroach-

15 (1915) 215 N. Y. 495, affirming (1913) 154 App. Div. 397. 
ments from the areas, streets and blocks where they had always before been permitted. When the late Mr. Justice Patterson wrote the opinion in the case of Broadbelt, there was nothing to indicate that there would ever be a radical departure from the early policy of the city with reference to building encroachments on the streets. Since then the change has become an accomplished fact, and its binding force has been recognized in the later judicial decisions. ${ }^{.16}$

The explanation thus offered is of the simplest. Reduced to its lowest terms it is this: the court declared that it yielded to the changed attitude of the municipal authorities as to the necessity for putting an end to the appropriation of the streets by private owners. If this explanation is correct, then we have an admirable instance of a process which is supposed to be characteristic of our common or unwritten law: its flexible and skilful adaptation to the evolutionary progress of the people and its constant improvement to meet new conditions as they arise. Unfortunately, however, the explanation is not borne out by the record or the facts. It was the municipal authorities who yielded to the courts rather than the courts who yielded to the municipal authorities. In the firsi place, as we have seen, upon a comparison of opinions we find the court holding at one time that the legislature had power to authorize the appropriation of a part of the street by abutting owners for their private benefit, and at another time that such an appropriation was violative of fundamental constitutional provisions. This was the real point upon which the court changed its opinion, but it was a point as to which a change in attitude by the municipal authorities would naturally be disregarded as immaterial and of no weight. It was for the court, and not for the municipality, to pass upon the extent of legislative powers. In the second place, an examination of the opinion in the Ackerman case, the one which revolutionized the position of the courts, discloses no reference to any change of attitude by the municipal authorities on any question, least of all on the question of encroachments on the street, and nothing to indicate that the Court of Appeals had been made aware of any such change at all. If the change in the municipal attitude was in fact the cause of the judicial change, we should naturally expect to find some mention of that fact in the judicial opinion. In the third place, and finally, the judicial records

${ }^{16}$ Acme Realty Co. v. Schinasi (1915) 215 N. Y. 495, 502, 504-5. 
themselves show that the court is wrong in its history, and that the change on the part of the municipal authorities followed the change on the part of the Court of Appeals, rather than vice versa. In Mr. Justice Clarke's opinion in the Appellate Division in the Schinasi case, ${ }^{17}$ which was, as we have seen, expressly adopted by the Court of Appeals, he quoted the two extracts from the Broadbelt and Levy cases which we have already cited, and then he went on to say:

"Neither of those opinions could have been written at the present date. The tremendous growth of the city in the last decade, the hurrying throngs who press through its congested streets and avenues, have required the widening of the roadways and the clearing of the sidewalks. The action of the city authorities has not only had the approval of the courts but they have compelled them to take action. (People ex rel. Cross Co.v. Ahearn, I24 App. Div. 840; People ex rel. Ackerman v. Stover, I38 id. 237; People ex rel. Browning King \& Co. v. Stover, 145 id. 259.) And there is submitted in the brief of counsel a table, which is not questioned, of the resolutions passed by the municipal authorities directing the removal of encroachments in the public streets, fifty-two in number, passed between July 29, 19I0, and March 7 , I912, covering all parts of the city." 18

Thus it appears that the steps which the city authorities took to remove the encroachments from the business streets of the city and which the courts cite as the occasion of their reversal of view, did not even begin until July, I9ro. This was seven years after the Ackerman case was decided. During that interval the municipal authorities had twice refused to take the action which the Ackerman case had clearly pointed out as their legal duty, and twice the courts had been compelled to enforce the performance of their legal duty by writs of mandamus. In the case of People ex rel. Cross Co. v. Ahearn ${ }^{10}$ a writ of mandamus to remove encroachments was issued to the borough president, and in the case of People ex rel. Ackerman v. Stover ${ }^{20}$ a similar writ was issued to the park commissioner. In both cases the city authorities strenuously resisted the courts in their efforts to compel the removal of encroachments, even to the

${ }_{17}$ Acme Realty Co. v. Schinasi (1913) I54 App. Div. 397, 410.

18 Acme Realty Co. v. Schinasi (rgr3) I54 App. Div. 397, 4ro-r1.

10 (1908) 124 App. Div. 840.

20 (1910) I38 App. Div. 237. 
extent of involving the city in the cost of two unfounded and fruitless appeals. The history of the second case is of considerable interest as showing the final outcome of Mrs. Ackerman's historic efforts to secure the removal of obnoxious bay windows. In her action against True she had been defeated in the lower courts, and it was not until she had been victorious in the Court of Appeals that she was in a position to enforce her rights. After she had secured the full declaration of her rights in the Court of Appeals, however, she found herself practically robbed of the fruits of her victory because, during the litigation, the defendant had transferred his property, with the result that the Appellate Division ultimately felt itself obliged to dismiss her action upon the ground that it could not compel True to enter upon property which he had ceased to own, even for the purpose of removing an encroachment which was illegal and which he himself had constructed.21 Thereupon Mrs. Ackerman brought proceedings for a mandamus against the park commissioner, who, in spite of the clear and unambiguous decision of the Court of Appeals in the action against True, refused to fulfil his legal duty as therein clearly set forth and appealed to the Appellate Division. ${ }^{22}$ It was not until after he had been defeated that the municipal authorities finally began to take action.

The conclusion is inevitable that the explanation of the Court of Appeals is incorrect and does not explain. It leaves the change of opinion, and the reasons for it, as much of a mystery as before. The change, however, took place; it was radical, and it was recognized as such both by the Appellate Division. and the Court of Appeals. Thus in the Williams case, the Appellate Division said:

"Whatever cases may be in the books must be held to be overruled by the Ackerman and the McMillan casesuntil, at least, the Court of Appeals has again passed upon the question." 28

This was followed by the declaration of the Court of Appeals that

"Our decision of Ackerman v. True has been followed in several well considered opinions by the Appellate Divi-

\footnotetext{
21 Ackerman v. True (1907) r20 App. Div. 172.

22 People ex rel. Ackerman v. Stover (1910) 138 App. Div. 237.

${ }^{2 s}$ Williams v. Silverman Realty \& Construction Co. (1906) III App.
} Div. 679. 
sion of the Supreme Court and its authority should not now be questioned."24

In support of its position, it cited the very $W^{\text {illiams }}$ case which characterized its action as an overruling of prior decisions. In a still later case, in response to an argument of counsel based upon some of its prior decisions, the court said:

"This is doubtless the view expressed in some of the earlier cases, such as Broadbelt v. Loewe (I5 App. Div. 343; affirmed by this court on the opinion below in $I 62$ N. Y. 642); but those decisions have been superseded in the more recent cases of Ackerman $v$. True (I75 N. Y. 353); City of N.Y. v. Rice (Ig8 N. Y. I24) and others which have followed them." ${ }^{*}$

The Broadbelt and the earlier cases have been overruled and swept away. The incident is closed. It is settled for all time that the legislature has no power to authorize abutting owners to appropriate public property for their private uses. We say "for all time," and this is indubitably correct. It is obviously the right solution, and, because it is right, we may safely assume that it will never be reversed. As a matter of fact, it has always been the right solution. As the Court of Appeals has itself declared:

"The title to the streets of the City of New York rests in the municipality as trustee for the public, and no grant or permission can be legally given that will interfere with their use by the public. The right of the public to use the streets is absolute and paramount (Deshong $v$. City of N. Y., I76 N. Y. 475,483). This has always been the law applicable to the public streets of the iCity of New York." ${ }^{26}$

But if that has always been the law, what of those decisions of the iCourt of Appeals to the contrary? If it has always been the law that the legislature has no power to authorize the private appropriation of public property, what of the decisions of the Court of Appeals declaring that it possessed such a power? The answer is clear, instant, and inexorable, and yet most diffcult of comprehension by a people trained in our system of jurisprudence: those decisions of the Court of Appeals were

24 City of N. Y. v. Rice (19ro) I98 N. Y. 124, I31.

${ }^{25}$ Acme Realty Co. v. Schinasi (1915) 215 N. Y. 495, 504

${ }^{20}$ Acme Realty Co. v. Schinasi (Ig15) 215 N. Y. 495, 502. 
not the law-even at the time they were rendered. In spite of what the Court of Appeals said in I900, the legislature of the State of New York did not have in 1900 any power to authorize abutting owners to appropriate any part of the street to their private gain. Even the opinion of the ICourt of Appeals could not confer a power which the people had withheld.

But if the opinion of the Court of Appeals as to the power of the legislature was not the law, what of the mandates which it issued pursuant to that opinion? The answer is similarly clear, instant, and inexorable, and equally difficult of comprehension by our people: those mandates were unlawful at the very instant of their issuance.

The conception of an unlawful mandate issuing from a court of last resort with lawful power to determine the cause before it may seem absurd and impossible; but it is neither absurd, nor impossible, and is, on the contrary, necessary, logical, and correct.

No human institution can be free from error. Even a tribunal charged with the administration of the law will at times commit mistakes, and instead of enforcing the law, will issue commands which are in violation of the law. Thus, when the Court of Appeals $^{2 \tau}$ declined to restrain the construction of a bay window which unlawfully encroached upon the street, upon the ground that the legislature had authority to authorize the encroachment, it negatively failed in the performance of its duty to enforce the law, and unlawfully deprived the plaintiff of his rights. Again, when, upon the same ground, it enjoined a public official from performing his duty to remove unlaw ful encroachments on the street, it affirmatively violated its duty to enforce the law by forbidding compliance with the law. ${ }^{28}$ These were unlawful acts by a court of last resort.

To accept the fact that even a court of last resort can, and often does, act unlawfully is not in any sense to impugn its uprightness, or intelligence, or efficiency: it is merely to recognize the indubitable fact that to err is human.

There must, of course, in the practical administration of every State come a point of time at which resistance to illegal commands must cease, although they are illegal. If an executive official issues an illegal command, the citizen may refuse to

27 Worinser v. Brown (1896) I49 N. Y. 163.

28 Hoey v. Gilroy (1892) I29 N. Y. I32. 
obey it and challenge its validity in court. If the judgment of the court of first instance sustains the illegal command, the citizen may appeal; but in any system, and in any controversy, at some time appeals must cease and, rightly or wrongly, an ultimate decision must be reached. Therefore we establish courts of last resort, and' we accept the fact that their decision in a particular controversy, whether right or wrong, shall be final in that cause. It does not follow, however, that it is right because it is final, and we shall never understand our own system of jurisprudence until we understand that final decisions may be erroneous, that they may not be the law, and that they may, in fact, be affirmatively illegal.

As a matter of fact, we do vaguely understand it. We do vaguely perceive that the final decisions of the courts of last resort may be wrong, and we adopt various devices to correct their errors. Sometimes we correct them by changing the constitution; sometimes we correct them by statute; sometimes we try to correct them by the recall of decisions; but more frequently we leave it to the court of last resort to correct its own errors of its own accord.

Of all methods of correcting judicial errors, the judicial method is obviously the wisest, the most effective, and the most just. The mere fact that there has been error signifies that there has been injustice and the courts are better fitted to cope with injustice than any other departmient of an organized state. Our courts should always be ready, therefore, to apply to their own errors and injustices the judicial method of correction. A frank acknowledgment that they can be, and are, on occasion, mistaken, and an open-minded reception of lawyer-like and respectful arguments tending to point out errors, will not in the slightest degree undermine their authority, or diminish the respect in which they are held. On the contrary, the more tolerant and approachable the court is, the greater will be the popular confidence in its decisions. In fact, the strongest bulwark which the courts can erect against the recall and other insidious attacks upon our judicial system will be found in the recognized practice by the courts themselves of the principle that judicial errors are to be judicially corrected.

New York Bar.

Everett V. Aвbot. 